\title{
Honning som sårbehandling
}

\author{
Interessen for honning som sårbe- \\ handlingsmiddel øker etter hvert som \\ bakteriene blir mer resistente mot \\ antibiotika.
}

In vitro-studier utført i vårt laboratorium kan tyde på at sterilisert honning kan bli et nyttig sårbehandlingsmiddel (1). Effekten av en steril australsk terapeutisk honning (Medihoney) og norsk skogshonning ble testet på flere antibiotikaresistente bakteriearter, inkludert meticillinresistente gule stafylokokker (MRSA). Begge honningene drepte alle de undersøkte typer bakterier. Det er imidlertid verdt å merke seg at norsk honning solgt som mat kan inneholde sporer og ikke er tilstrekkelig filtrert eller sterilisert til å kunne brukes på sår.

Flere kliniske studier med standardisert sterilisert CE-merket honning er publisert. I tillegg til bakteriedrepende effekt er det rapportert om rask tilheling av kroniske sår, nøytrofil stimulering $\mathrm{i}$ såret $\mathrm{og}$ mindre arrdanning ved bruk av honning.

Terapeutiske honningprodukter er nå tilgjengelig i Norge. Bruk av honning i sårbehandlingen kan bidra til sårheling,

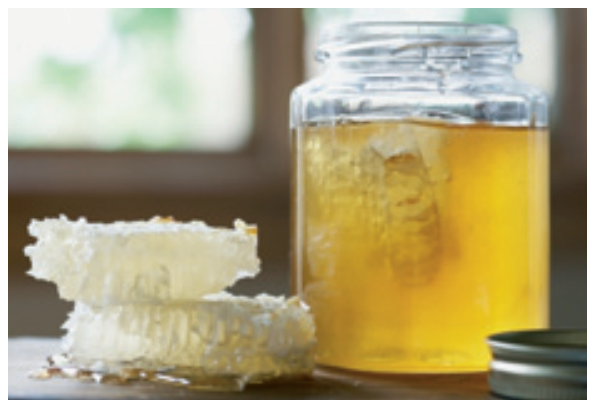

Illustrasjonsfoto Kate Kunz, Veer/SCANPIX

til forebygging av invasiv infeksjon og utbrudd av resistente bakterier, til fjerning av dårlig lukt fra såret og til bevaring av de antibiotika som vi har igjen.

\section{Patricia Merckoll}

patricia.merckoll@ulleval.no

Mikrobiologisk avdeling

Oslo universitetssykehus, Ullevål

\section{Litteratur \\ . Merckoll P, Jonassen TØ, Vad ME et al. Bacteria, biofilm and honey: a study of the effects of honey on «planktonic» and biofilm-embedded wound bacteria. Scand J Infect Dis 2009; 41: 341-7.}

\section{Dødsårsaker ved snøskredulykker}

\section{Kvelning og traumer er de vanligste dødsårsakene ved snøskredulykker. Fordelingen mellom disse varierer for ulike typer aktivitet. Det viser en kanadisk studie.}

De vanligste dødsårsakene ved skredulykker var asfyksi (75\%), traume (24\%) og hypotermi (1\%). Studien dekket perioden 1984-2005 og omfattet 204 døde, hvorav 117 ble obdusert og 87 ble rettsmedisinsk undersøkt (1). Av isklatrerne var andelen traumatisk døde $42 \%$, mot kun $9 \%$ av snøscooterkjørerne. Av heliskikjørerne døde $30 \%$ av traumer. Thoraxtraumer (46\%) og hodeskader (42\%) var vanligst blant døde med skade i én region. Nakketraumer og abdominaltraumer sto for hhv. $8 \%$ og $4 \%$ av skadene. Traume var medvirkende dødsårsak ved $10 \%$ av asfyksidødsfallene. Blant traumeofrene var $48 \%$ fullstendig nedgravd, mot $92 \%$ av asfyksiofrene.

- Det er ikke gjort noen studier på dødsårsaken hos dem som blir tatt av skred i Norge, men fra Alpene er det publisert en del. På bakgrunn av disse resultatene har det vært konsensus i det internasjonale medisinske snøskredmiljøet at ca. $95 \%$ av de omkomne dør av kvelning eller hypotermi og bare $5 \%$ direkte av traume, sier lege Øyvind Thomassen ved Kirurgisk serviceklinikk, Haukeland universitetssykehus.

- Denne ulikheten i dødsårsak mellom snøskredofre i Europa og Canada kan skyldes både metodiske, geografiske og kulturelle årsaker. I Canada går flere skred i skogsterreng, der det er større risiko for at den som blir tatt av skredet treffer fysiske hindringer. Bruken av søker- og mottakerutstyr og profesjonelle guider er høyere i Canada enn i Europa, hvilket medfører at median tid før fremgraving er kortere der. Dette resulterer i at flere overlever fordi de blir funnet før kvelningsdøden inntrer, sier Thomassen.

\section{Mette Sagsveen}

msagsveen@yahoo.com

Tidsskriftet

\footnotetext{
Litteratur

. Boyd J, Haegeli P, Abu-Laban RB et al. Patterns of death among avalanche fatalities: a 21-year review. CMAJ 2009; 180: 507-12.
}

\section{Monoklonale antistoffer i kreftbehandling}

Monoklonale antistoffer mot HER2- og EGFR-proteinene har vist seg effektive $i$ behandlingen av noen krefttyper, men resistensutvikling er et problem. Ved å kombinere ulike antistoffer mot HER2proteinet har forskere nå funnet at visse kombinasjoner av monoklonale antistoffer er mer effektive enn andre (Proc Natl Acad Sci USA 2009; 106: 3294-9).

En israelsk forskergruppe har i musemodeller demonstrert at inklusjon av ikkeinhiberende monoklonale antistoffer rettet mot den epitopen av HER2-proteinet som er involvert i dimeriseringen bidrar til effekten. Deres hypotese er at noen antistoffkombinasjoner bidrar til endocytose av HER2-proteinet. Dette er i så fall en ikke-immunologisk mekanisme.

\section{Genetisk påvirkning av hjerneaktivitet}

Det kan være vanskelig å påvise en direkte kobling mellom gener, hjerne og atferd. Hjernestudier har vist at noen gener er uttrykt i meget spesifikke regioner, mens andre har mer globale effekter. Nå har en internasjonal forskergruppe studert forskjeller i hjerneaktivitet hos tvillinger ved hjelp av funksjonell magnetresonansavbildning (Science 2009; 323: 737-9).

Det ble påvist en betydelig genetisk påvirkning ved aktivering av nevronale nettverk under oppgaver som involverte tallhukommelsen. Det var genetiske påvirkninger av hjerneaktiveringen i kretser relevant for språk som var atypiske for tallhukommelse. Genetiske effekter ble hovedsakelig funnet i hjerneregioner som ikke var aktivert hos alle deltakerne, det gjaldt spesielt ved utføring av krevende oppgaver. Individuelle forskjeller i kognitive funksjoner kan derfor være et resultat av ulike hjerneaktivitetsmønstre med bakgrunn i genetiske faktorer.

\section{Ustekinumab ved psoriasisartritt}

Medikamentet ustekinumab gir færre symptomer og mindre hudlesjoner enn placebo hos pasienter med psoriasisartritt. Det er konklusjonen i en randomisert, placebokontrollert fase 2-studie publisert i The Lancet $(2009$; 373: 633-40).

Pasienter med aktiv psoriasisartritt ble randomisert til å få ustekinumab hver uke i fire uker (uke 0-3) og placebo i uke 12 og 16 (gruppe 1) eller placebo i uke $0-3$ og ustekinumab i uke 12 og 16 (gruppe 2).

I uke 12 var det symptombedring hos tre ganger så mange pasienter i gruppe 1 (42\%) som i gruppe 2 (14\%). Hos dem med psoriasis på minst $3 \%$ av kroppsoverflaten var det hos $52 \%$ i gruppe 1 og $5 \%$ i gruppe 2 minst $75 \%$ forbedring når det gjaldt utbredelse og alvorlighetsgrad av sykdommen i uke 12. 